\title{
Education, Attitudes, and Language of Higher Education: Francophone Students in Northern Ontario
}

\section{DEREK WILKINSON*}

\begin{abstract}
Data from 1586 Francophone students in Northeastern Ontario concerning their attitudes towards French and English show seven independent factors affect linguistic beliefs. Three factors -believing French unimportant, believing English practically dominant, and believing their French inadequate - lead students to continue their post-secondary education solely in English. Believing French more pleasurable is positively, and believing English superior is negatively, related to continuing post-secondary education solely in French. Educational level is negatively related to believing English superior and to believing French unimportant but positively related to believing English dominant, French pleasurable, and their French inadequate. Policy should therefore focus on countering the belief in English dominance and the belief in the inadequacy of their ability in French.
\end{abstract}

* Laurentian University

I should like to thank Dr. Simon Laflamme who allowed me to use the data and his basic SPSS program to initially read it, and who made perceptive critiques of the final version, Sylvie Lafreniere and Joanne Tremblay who as students in my French methodology class learned about analysis of variance and factor analysis using this data set as an example, and Dr. Dieter Buse and Si Transken who gave detailed recommendations for great textual change. Three anonymous reviewers for CJHE also made helpful comments as did Maurice Aumond, my critic at the CSSHE Annual Meeting in Ottawa, 1993, where an earlier version of this paper was presented. 


\section{Résumé}

Les données recueillies par Laflamme et Dennie (1990) auprès de 1586 étudiants francophones du Nord-Est de l'Ontario, données portant notamment sur les attitudes envers le français et l'anglais, révèlent sept facteurs déterminants des croyances linguistiques. Trois facteurs - croire que le français n'est pas important, que l'anglais est en réalité dominant et que le français qu'on parle est inadéquat - incitent les étudiants à poursuivre leurs études en anglais seulement. Croire que le français constitue, plus que l'anglais, une langue de plaisir est positivement relié au fait de poursuivre des études postsecondaires en français seulement, alors que tenir l'anglais pour une langue supérieure est négativement relié au fait de poursuivre des études en français seulement. Le niveau d'éducation est négativement relié à la croyance en la supériorité de l'anglais et à celle en la non-importance du français, mais il est relié positivement au fait de croire en la domination de l'anglais, au français comme langue de plaisir et au manque de compétence à s'exprimer dans sa langue. Par conséquent, les décisions politiques devraient veiller à contrecarrer la croyance en la domination de l'anglais et celle en l'incompétence de la personne dans sa langue.

\section{Introduction}

Relatively few Francophones in North Eastern Ontario undertake university studies. Some of those who enroll elect to continue their studies entirely in English. An important role of bilingual universities outside Quebec and their supporters is to encourage students to continue their education in French. This means convincing students who can continue in French to do so. When Francophone students choose to pursue some or all of their post-secondary education in English, this represents a serious problem for the continuation of academic French culture in North Eastern Ontario. It creates an administrative problem for educators committed to providing a range of choice for Francophones in higher education, because provision of courses often requires demand. Maintenance of the demand for Francophone courses is an important policy objective for bilingual universities.

Pursuing this objective requires understanding students' choices which in turn means finding out students' own reasons for selecting programs. Choices are made in the context of beliefs about the social world and one's place in it. In order to influence the choices, it is necessary to identify the main beliefs and attitudes. Such main beliefs and attitudes are rarely individual and isolated; they 
occur in constellations, influence the answers to a number of questions, and affect multiple aspects of action. Choosing to follow instruction in English or in French is rational in the sense that it is consistent with the constellations of attitudes which individuals hold. Altering such choices requires strengthening or weakening beliefs related to these attitudes. This process is neither instantaneous nor impossible to achieve. To be most effective, it requires empirical investigation of the relationships between attitudes, actions, and choices.

Laflamme and Dennie (1990) showed that there is a genuine Francophone Ontarian culture with common elements underlying the apparent conflicts. An important aspect is the dialectic between self-esteem and the vision of the other. Their conclusion is that Frenchness (francité) tends to increase with education and age.

Quoi qu'il en soit l'instruction consolide de toute évidence le francophone dans sa culture (p. 146).

Nevertheless, it is important to remember that individuals in practical situations have a wide variety of beliefs about language which are not always structured according to theoretical or philosophical classifications. This study uses factor analysis to look at the actual ways in which these beliefs are structured in the minds of students in the educational system in Northern Ontario. The intention of this article is to describe the inter-relations of linguistic attitudes as a precursor to the possible development of a theory and to show the relations of these attitudes to choice of language of further education and grade level as an aid to practical decisions about language policy. It answers three new questions. (1) How many independent dimensions are necessary to characterize the variation in students' attitudes towards the two languages? (2) Which dimensions influence students to continue their education in French? (3) How are these dimensions themselves influenced by the students' earlier education?

\section{Methodology}

Data were collected by Laflamme and Dennie from 1,586 Francophone students in North eastern Ontario concerning their attitudes towards French and English (Laflamme \& Dennie, 1990). The language items in the original study consisted, among others, of a large set of statements about English and French language and culture. The item pool attempted to cover all of the attitudes towards language and language users which could be relevant in describing FrancoOntarians. For each question, the respondent had to agree or disagree on a fivepoint Likert scale. ${ }^{1}$ The variables used here were the language items, the grade, and the intended language of further education. 
To categorize empirically the different aspects of beliefs about language, factor analysis with Varimax rotation was used. Where a variable loaded maximally on a factor on which less than two other variables loaded maximally, that variable was deleted. This result is a classification of items or beliefs into the smallest possible number of categories called factors which explain variation in answers. The procedure calculates a score on each of these factors.

To investigate the factors' effects on language choice for higher education, analysis of variance was used. Possible language choices were French only, bilingual, and English only. Analysis of variance shows whether there are differences among the three means. To find out which means significantly differed from others we used the Scheffé post hoc test, a relatively conservative test.

To investigate grade effects on belief patterns, analysis of variance for linear trends was conducted since the grade intervals are equally spaced. Interest was in the overall trends rather than in specific differences between particular means. A test for quadratic trend was also included in case a linear trend was not constant over the period.

\section{The Dimensions of Language Beliefs}

The seven factors resulting from Varimax factor analysis which describe the constellation of language attitudes are presented in Table 1. Table 1 shows those variables which load on each of the seven factors. Ten variables which did not load on our factors were excluded from the analysis. ${ }^{2}$ Only the highest loadings are presented for each factor, and each item is presented for the factor on which it has the highest loading.

The first factor represents the superiority of English culture. The three items loading highest on the factor relate to entertainment and its interest. ${ }^{3}$ The first five items on this factor were classified as items concerning culture by Laflamme and Dennie. Of the last two, "English as a rational language" was classified as value and "English culture is the greatest culture in the world" was classified as supremacy of English. The factor then appears to represent the element of attachment and feeling for language in leisure activities, in activities which are not as strongly constrained by external norms. The item about rationality of English seems somewhat anomalous in this factor but it has a lower weighting. This factor represents significant agreement between the categorizations of Laflamme and Dennie and our empirical analysis which shows variables falling into their categorization of culture. ${ }^{4}$

The second factor represents the belief that French is not important (refer to factor 2 in Table 1). This factor seems to separate individuals who think French 
Table 1

The seven varimax factors underlying language items

\begin{tabular}{|c|c|c|}
\hline Factor & Language Item & Weight \\
\hline 1 & $\begin{array}{l}\text { - Television is much more interesting in English than in French / } \\
\text { La télévision est bien plus intéressante en anglais qu'en français } \\
\text { - The best films in the world are English / } \\
\text { Le meilleur cinéma au monde est anglophone } \\
\text { - Popular songs are more captivating in English than in French / } \\
\text { La chanson populaire est plus poignante en anglais qu'en français } \\
\text { - It's easier to read in English than in French / } \\
\text { C'est plus facile de lire en anglais qu'en français } \\
\text { - English culture is much more interesting than French culture / } \\
\text { La culture anglaise est plus intéressante que la culture française } \\
\text { - English is a more rational language than French / } \\
\text { L'anglais est une langue plus rationnelle que le français } \\
\text { - English culture is the greatest culture in the world / } \\
\text { La culture anglaise est la plus grande culture au monde }\end{array}$ & $\begin{array}{l}.75 \\
.73 \\
.70 \\
.52 \\
.45 \\
.43 \\
.42\end{array}$ \\
\hline 2 & $\begin{array}{l}\text { - The quality of my French is not important / } \\
\text { La qualité de ma langue française n'est pas importante } \\
\text { - It is important not to be too French / } \\
\text { Il ne faut pas être trop français } \\
\text { - It is more important to study in high school in English than in French / } \\
\text { C'est plus important de faire ses études secondaires en anglais qu'en français } \\
\text { - Our teachers don't encourage us to live in French in our schools / } \\
\text { Nos enseignants ne nous encouragent pas à vivre en français dans nos écoles } \\
\text { - It is much more important to get a good job than to continue one's studies / } \\
\text { Il est beaucoup plus important d'obtenir un bon emploi que de poursuivre } \\
\text { des études } \\
\text { - It is pointless to fight for French; you have to be realistic; } \\
\text { after all you can't teach all the English people to speak French / } \\
\text { Ça ne donne rien de se battre pour le français; il faut être réaliste; } \\
\text { après tout on ne va pas enseigner à tous les anglais à parler français } \\
\text { - French culture is old-fashioned / } \\
\text { La culture francophone n'est plus à la mode }\end{array}$ & $\begin{array}{l}.62 \\
.60 \\
.55 \\
.53\end{array}$ \\
\hline 3 & $\begin{array}{l}\text { - In reality, economic power in society belongs to the English / } \\
\text { En réalité, le pouvoir économique, dans la société, appartient aux } \\
\text { anglophones } \\
\text { - In reality, political power in society belongs to the English / } \\
\text { En réalité, le pouvoir politique, dans la société appartient aux anglophones } \\
\text { - In reality, scientific power in society belongs to the English / } \\
\text { En réalité, le pouvoir scientifique, dans la société appartient aux } \\
\text { anglophones } \\
\text { - In society, in reality, people function in English / } \\
\text { Dans la société, en réalité, on fonctionne en anglais }\end{array}$ & $\begin{array}{l}.74 \\
.47\end{array}$ \\
\hline
\end{tabular}


Table 1 (continued)

\begin{tabular}{|c|c|c|}
\hline Factor & Language Item & Weight \\
\hline 4 & $\begin{array}{l}\text { - Francophones are more fun than Anglophones / } \\
\text { Les francophones sont plus amusants que les anglophones } \\
\text { - The English don't know how to have fun / } \\
\text { Les anglophones ne savent pas vraiment s'amuser } \\
\text { - I enjoy myself more in French than in English / } \\
\text { Je préfere m'amuser en français plutôt qu'en anglais } \\
\text { - French is a language of life; English is a language of work / } \\
\text { Le français est une langue de vie; l'anglais est une langue de travail }\end{array}$ & $\begin{array}{l}.75 \\
.66 \\
.66 \\
.46\end{array}$ \\
\hline 5 & $\begin{array}{l}\text { - It's irritating to hear a Francophone speak English with an accent / } \\
\text { Il est irritant d'entendre un francophone qui parle anglais avec un accent } \\
\text { - It's bothersome for a Francophone to hear another Francophone } \\
\text { speak English in public when he/she has a French accent / } \\
\text { Il est gênant, pour une francophone, d'entendre un francophone parler } \\
\text { anglais en public quand il a un accent français } \\
\text { - I am ashamed to identify myself as a Francophone at a party / } \\
\text { J'ai honte de m'identifier comme francophone dans un «party» }\end{array}$ & $\begin{array}{l}.73 \\
.43\end{array}$ \\
\hline 6 & $\begin{array}{l}\text { - I am ashamed of the quality of my French / } \\
\text { J'ai honte de la qualité de ma langue française } \\
\text { - I am ashamed to start speaking to other people in French / } \\
\text { J'ai honte de m'adresser aux personnes d'abord en français } \\
\text { - The feeling of living in English is more natural than the feeling } \\
\text { of living in French / Je ressens le goût de vivre en anglais comme } \\
\text { étant plus naturel que celui de vivre en français }\end{array}$ & $\begin{array}{l}.70 \\
.62 \\
.44\end{array}$ \\
\hline 7 & $\begin{array}{l}\text { - Francophones should not ask for too much because they might shock } \\
\text { Anglophones / Les francophones ne doivent pas trop demander parce } \\
\text { qu'ils vont choquer les anglophones } \\
\text { - French is a language of the heart; English is a language of the head / } \\
\text { Le français est une langue de plaisir; l'anglais est une langue de tête } \\
\text { - It is not important to ask for services in French / Il n'est pas nécessaire } \\
\text { de réclamer des services en français }\end{array}$ & $\begin{array}{l}.70 \\
.56 \\
.40\end{array}$ \\
\hline
\end{tabular}

is important on a personal basis. Most of the items relate to the importance of the language of studying or of schooling. Thus we might say this relates to the import of French education. The first three items on this factor were categorized by Laflamme and Dennie as concern with language. Future encouragement and old-fashionedess of French culture were categorized by them as culture while the importance of a good job was categorized by them as value, and the pointlessness of fighting over French was categorized by them as supremacy. The fact that there is so much change raises a question about the unidimensionality of their concern for language category. More conceptualization is required in this area. ${ }^{5}$ 
The third factor represents the belief that in the world of practical affairs, English is dominant (refer to factor 3 in Table 1). Obviously, this factor represents the view that power in society is associated with English. Interestingly, respondents do not seem to differentiate greatly among economic, political, and scientific power. This may be a result of their position outside of the power structures. On this factor, all of the items were categorized by Laflamme and Dennie as supremacy. They also included under supremacy the beliefs that "English culture is the greatest culture in the world," "It is pointless to fight for French," and "Francophones should not ask for too much." That these latter three items are not included in this factor suggests that those answering the questionnaire differentiated the fact of power from feelings of pointlessness and cultural values in ways that Laflamme and Dennie had not considered.

The fourth factor represents the belief that leisure is more pleasurable in French (refer to factor 4 in Table 1). This factor represents the idea of French as fun. This differs from the earlier factor which represents more structured entertainment. Laflamme and Dennie characterize all these items other than the enjoyment item as part of their value judgement category. Enjoying themselves more in French than in English is classified by them under culture. They also classify "English is a more rational language" and "It is important to get a good job rather than to continue studies" as part of value judgments. The specific value judgements which are joined here do relate to French people having more fun. Consequently, it is reasonable to distinguish between this aspect of values and value judgements in general.

The fifth factor represents the belief that a French accent is inferior (refer to factor 5 in Table 1). This factor might well be called Accent - Rejection or Accent - Inferiority. Presumably, it relates to self-esteem for a Francophone identity. All three of the items loading high on this factor are characterized by Laflamme and Dennie as part of shame; however, they also characterized the first two items on the next factor as relating to shame. Our analysis differentiates between two aspects of shame: shame at being a Francophone, and shame at the quality of the person's French.

The sixth factor represents a sense of shame at the quality of the respondent's French (refer to factor 6 in Table 1). This factor may relate to the belief that French is difficult to use - that respondents are made to feel badly about their French, in this case while speaking French rather than English. We can call this factor the Inadequate French symptom, the view that their French does not measure up to others' standards. That would diminish their taste for living in French. It is an important difference between our account and that of Laflamme 
and Dennie that this specific factor is separated out in our analysis. It indicates that the feeling of shame at the quality of personal French language differs from a general feeling of shame about being Francophone.

The seventh factor represents a belief that it is not good to insist on service in French (refer to factor 7 in Table 1). The items on this factor were classified by Laflamme and Dennie in the order in Table 1 as part supremacy, culture and concern for language. Indeed, the underlying basis for the constellation of these items is not clear. However, this factor may relate to a view that Francophones should not be active politically as a community and not take an individually involved position.

What the results of the factor analysis show is that attitudes toward language do not group into the categories one would imagine intuitively or even theoretically. Our account shows that the structure of beliefs with respect to these items is relatively complicated in the population in question. Factors where this analysis differs most from the theoretical account of Laflamme and Dennie (1990) are the superiority of English culture, the belief that French is not important, and the categorization of shame into two separate components. Further research is required to explain why beliefs are structured in this way. ${ }^{6}$

\section{Attitudes Influencing Language of Post-Secondary Education}

One of the aims of analyzing the set of linguistic attitudes was to determine what kinds of attitudes and beliefs impelled students to continue their education in French. In this section, we analyze how the different factors relate to the intention to follow post-secondary education in French. It might seem to some that the effects of these beliefs on the probability of taking courses in French is obvious; indeed, one of the earlier reviews of this article suggested just that. However, it is important to provide empirical answers to this question. Our answers result from analysis of variance of the means on each factor for three groups: those who will take their studies in French; those who will take them in English; and those who will take them in both. ${ }^{7} \mathrm{~F}$ statistics and $\mathrm{p}$ values are reported for each factor in Table 2 .

For the superiority of English culture, factor one, differences among the three groups are significant. Those who plan to continue in French score significantly lower on this factor than the other two groups. ${ }^{8}$ This indicates that a belief in the superiority of English inclines students to take courses in English or English and French in their post-secondary education. Understandably so, for a belief that they will learn more and be better skilled by taking some of their education in English would influence their choices. 
Table 2

Means and analysis of variance for language factor scores in relation to planned language of further education

\begin{tabular}{c|ccc|cc} 
& \multicolumn{2}{|c|}{ Planned Language Group Means } & \multicolumn{2}{|c}{ ANOVA } \\
Factor & French & $\mathrm{E}+\mathrm{F}$ & English & $\mathrm{F}(2 / 913)$ & $\mathrm{p}$ \\
\hline 1 & $-.05^{*}$ & .27 & .48 & 14.2 & $<.001$ \\
2 & -.10 & .03 & $.63^{*}$ & 17.8 & $<.001$ \\
3 & -.17 & -.13 & $.35^{*}$ & 10.8 & $<.001$ \\
4 & $.24^{*}$ & -.15 & -.41 & 18.8 & $<.001$ \\
5 & .16 & .06 & -.06 & 1.8 & .17 \\
6 & -.13 & -.03 & $.45^{*}$ & 11.4 & $<.001$ \\
7 & .00 & .04 & .05 & .2 & .85 \\
\hline
\end{tabular}

* Significantly different from other two means using Scheffé post-test

For the second factor, that French is not important, again there were significant differences among the three groups. Those who planned to continue in English scored significantly higher than the other two groups. This suggests that a belief that the French language is unimportant influences students to follow their future education solely in English.

For the third factor, the belief in practical English dominance, again there were significant differences among the three groups. Those who planned to continue in English had significantly higher scores. This supports the conclusion that the belief in English dominance influences students to take courses solely in English. Underlying this influence may be a growing tendency to consider that education has only instrumental significance - that one pursues education in order to obtain a job, i.e. for only practical purposes.

For the fourth factor related to pleasure in French, means were again significantly different for the three groups. Pleasure in French inclined students to continue and take their higher education in French. Clearly, an affective attachment to French is influential in students' decisions. Many students want to study and work in the language which they enjoy.

Factor six, inadequacy in French, showed significant differences among the three groups. Believing one was inadequate in French was very likely to incline a student to continue his or her education in English. Tepperman's (1988) discussion of incapacitation may be relevant to this phenomenon. People who are incapacitated under one categorization are likely to reject that categorization 
and substitute an alternate categorization which does not incapacitate them. This is a common process for minority group members. Criticizing some Francophones for their French may cause them to shift their identity and allegiance away from the French language. In a widely cited study, Willis (1977) showed that working class students in an occupational stream in a Birmingham school created their own oppositional culture, rejecting the mainstream organizational school culture which defined them as unsuccessful and inadequate. It would seem that Francophone students who are poor in school may defend their self-esteem by rejecting the values of the French culture which is being imposed upon them. This phenomenon warrants further study, preferably using ethnographic methods.

The two other factors, factors 5 and 7 , the belief that a French accent is inferior and the belief that it is not good to insist on service in French, were not significantly related to the choice of future language of education.

Thus, two factors separate those who plan to continue in French: belief in the superiority of English culture and belief in the pleasurableness of French. Three factors separate those who plan to continue in English: belief in the nonimportance of French, belief in the dominance of English, and belief in the inadequacy of their French.

\section{Education Influences Attitudes}

Since some of the belief patterns are strongly effective in determining who will continue in French, it is important to check how these patterns change with grade level. Does the level of schooling increase or decrease belief in specific linguistic factors ? $^{9}$ Grades 8 to second year of university or college are considered in this analysis. The main question here is whether or not there is a linear trend over the cycle. An additional question is whether this linear trend is constant over the period. The quadratic effect is a second order effect which essentially shows whether or not the linear effect is constant, or increases or decreases in slope, over the period. Means and significances for linear and quadratic effects are shown in Table 3.

For factor one, the superiority of English culture, there is a linear term and a quadratic term. The scores on this factor decrease significantly over the course of the student's career. Post-hoc tests show that most of the significant differences are between those in high school and those further advanced in education with those further advanced having lower scores. That is to say, as students proceed through the educational system, they are less likely to believe in the superiority of English culture. ${ }^{10}$ There may be some influence of exit on this 


\section{Table 3}

Means and linear and quadratic trend significances for language factors in relation to grade level

\begin{tabular}{|c|c|c|c|c|c|c|c|c|c|c|c|c|}
\hline & \multicolumn{8}{|c|}{ Means for Level of School and College or University } & \multicolumn{2}{|c|}{$\begin{array}{l}\text { Linear } \\
\text { Trend }\end{array}$} & \multicolumn{2}{|c|}{$\begin{array}{l}\text { Quadratic } \\
\text { Trend }\end{array}$} \\
\hline & 8 & 9 & 10 & 11 & 12 & 13 & 1 & 2 & $F$ & $\mathrm{p}$ & $F$ & $\bar{p}$ \\
\hline 1 & .30 & .27 & .29 & .20 & .11 & -.07 & -.56 & -.62 & 154.5 & $<.001$ & 25.6 & $<.001$ \\
\hline 2 & .14 & .17 & .23 & -.12 & -.04 & -.19 & -.26 & -.16 & 32.6 & $<.001$ & .21 & .65 \\
\hline 3 & -.21 & -.27 & -.01 & -.16 & -.06 & .35 & .23 & .28 & 50.2 & $<.001$ & .41 & .52 \\
\hline 4 & -.48 & -.13 & .13 & .04 & .13 & .07 & .21 & .33 & 68.7 & $<.001$ & 10.81 & $<.001$ \\
\hline 5 & .21 & .15 & .14 & .07 & -.18 & -.00 & -.25 & -.25 & 38.48 & $<.001$ & .02 & .90 \\
\hline 6 & -.05 & -.07 & -.14 & -.03 & .08 & .24 & -.04 & .20 & 7.03 & .01 & .29 & .59 \\
\hline 7 & .06 & -.02 & .21 & .19 & -.08 & -.16 & -.11 & -.12 & 7.37 & .01 & 1.44 & .23 \\
\hline $\mathrm{n}$ & 244 & 210 & 187 & 84 & 166 & 103 & 177 & 118 & & & & \\
\hline
\end{tabular}


relationship in that some of those students who do believe most strongly in the superiority of English may switch to the English school system and not be tapped by the questionnaire. However, this is unlikely to be the sole cause for the relationship we have found.

Factor two, that French is not important, declines significantly over the period of education." Table 3 shows that students as they continue in education are less likely to reject the importance of French. The change seems to be greatest between grades 10 and 11. Attachment to the French language is increased by the educational system.

Factor three, the belief in English dominance, increases significantly over the period of education, as shown in Table 3. Those with more education are more likely to believe that English is dominant. This belief increases in strength until grade 13.

Factor four, belief in French pleasurableness, significantly increases over the grade levels studied. Means are shown in Table 3. The significant quadratic component reasonably reflects the sudden increase on leaving elementary school and entering secondary school, but belief in the factor continues to rise thereafter. Those past grade nine are more likely to think that French is fun, and those in university or college are most likely to think this as well.

Factor five, the belief that a French accent is inferior, significantly decreases over the grade span as seen in Table 3. As people go up in grade level, they are more and more likely to believe in the acceptability of French in everyday and official life.

Factor six, belief that French is difficult to use, increases with education. Increases occur in grade 11 and then again in grade 13, as shown in Table 3. The more educated students are more likely to be ashamed of the quality of their French.

Factor seven, the belief that it is not good to insist on service in French, shows a significant decrease with level of schooling. Means are reported in Table 3. This represents a greater self-confidence in their linguistic community instilled by further education.

The effects of school level according to this study are to reduce beliefs in English cultural superiority, and in the un-importance of French. The effects of school level also increase beliefs in English dominance and in French as pleasurable and difficult to use. 


\section{Relationships of Education to Attitude and Choice}

The results cast some light on the effects of schooling indirectly through attitudes on language choice. In Figure 1, the arrows on the left represent positive or negative influences of increased schooling on those attitudes which influence language choice. Arrows on the right represent the influence of attitudes on language choice. Although there are three possibilities in terms of language choice, the only significant differences were between factors which increased or decreased the likelihood of taking courses solely in French, or factors which increased the likelihood of taking courses only in English. None of the attitudes increased or decreased significantly the likelihood of taking courses in both languages compared to the extremes. Consequently, we can represent the results with plus or minus and a letter indicating the language which is affected differently from the combined other-language-bilingual group.

Educational policy has been formed with the intention of reinforcing the choice of the French language for university studies. Indeed, Laflamme and Dennie (1990) consider that Franco-Ontarians may be unique among linguistic minorities in that the more educated among them are the most likely to maintain their minority language. However, to the extent that schooling instills the belief in the practical dominance of English and to the extent that it makes the individual believe his or her French is inadequate, it may move students to switch to English for their future education. There are studies which consider the relative costs to the community of language choice. Colomer (1990) models language dominance. His model shows that changing from bilingual to English has more serious effects on the language than does changing from French to bilingual. Hakuta (1986) finds that active rejection of bilingualism by second or third generation immigrants is a major factor in linguistic assimilation in the U.S. In both cases, the costs to minority (French) language users are greatest when individuals give up bilingualism for dominant monolingualism.

\section{Conclusion}

In this study a number of attitudes related to French and English were shown to be describable in seven dimensions. Two of these dimensions of language attitudes, believing a French accent not inferior, and believing one should not insist on service in French, were found in this study to be unrelated to decisions about the language to use in education. Believing French pleasurable and not believing English culture superior inclined students to continue in French. Believing English dominant, French non-important, and their own French inadequate 


\section{Figure 1}

Diagram of association between level of school type of belief, and choice of language of further education



$+=$ significant positive relationship

$E$ = taking courses only in English

- = significant negative relationship

$\mathrm{F}=$ taking courses only in French 
inclined students to continue in English. Level of schooling was generally associated with attitudes correlated with an increase in the probability of choosing French or a reduction in the probability of choosing unilingual English, except for two cases: level of schooling was associated with belief in the practical dominance of English and was associated with a self-conception that the student's own French was inadequate.

\section{Possible Implications}

In order to enhance the likelihood of students continuing their education in French, an attitudinal approach would concentrate on countering the two beliefs which schooling appears to foster and which decrease the probability of choosing French. The belief that English is dominant in practice could be somewhat countered by examples of the importance of French in community economic and political life. Examples of the practical use of French should be made available to students during their secondary school education. It is important to continue to emphasize such examples during students' post-secondary studies.

The other avenue would be to instill confidence in the students' ability to speak French. To the extent that schooling diminishes this confidence, it is counterproductive for the Francophone community. It is, therefore, important not to use self-esteem as a motivator for language in education since this threatens those who are less successful. A pronounced emphasis on grammar and grammatical correctness could have a significant negative effect on self-esteem. More avenues must be explored to teach the language without negatively prejudicing students' self-images.

It is unfortunate that a contrary sentiment has occasionally been expressed by some Francophone intellectuals in Northern Ontario. Defense of Francophone identity is seen as requiring rejection of Franglais and maintaining the purity of the French language. This has frequently been an issue in the personal lives of Francophone professionals who have themselves had to struggle to maintain an academic French style. Hence, it is almost automatic for them to denigrate French which does not meet their standards. My argument implies that they should not attempt to impose their standards; they should rather motivate by example and reward and encouragement, enticing students to want to develop their linguistic ability in an atmosphere devoid of threat and compulsion.

To develop a strong and vibrant Francophone community outside of Quebec, youth must be motivated to maintain their Francophone culture. The actual effects of school policies in this process can enhance or diminish this 
motivation. Ensuring that students gain self-esteem from their language and convincing them that English need not be dominant in practice are two steps which would help in this process.

\section{Notes}

1 The original book summarized these results and presented micro analyses of each question. It categorized language questions according to the pre-existent categories of shame, concern for language, supremacy of English, culture, and value judgements, in an attempt to describe, generally, the student population. It discussed individual beliefs. It is because the questions cover so much more than have those in other studies that it is worthwhile re-analyzing the data to cast light on new questions.

2 The following table shows the items not included in the factor analysis and the category assigned to them by Laflamme and Dennie.

- Il est mal vu de bien parler en français

- Il n'y a aucun danger d'oublier la langue française et on ne peut pas se permettre de ne pas parler anglais

- Il n'y a aucun danger d'oublier la langue française parce que au fond, le français, c'est un état d'âme qui ne disparaît pas

- Etant donné qu'on maîtrise déjà la langue française, il est important de se perfectionner en anglais

- La disparition du français, en Ontario, est inévitable

- Le français, dans le monde, est en voie de disparition

- La qualité de la langue anglaise est importante

- Les francophones ne sont pas faits pour occuper de hautes fonctions dans la société.

- Le français est une langue qu'on parle principalement à la maison

- Les anglophones ne savent pas vraiment s'amuser

conte

souci

souci

souci

souci

souci

souci

suprématie suprématie valeur

3 For those unfamiliar with factor analysis, it is important to emphasize that it is the items themselves which define the factor. Thus, what the factor represents must be guessed at from the common characteristics of the items which load highly on it.

4 This is a narrower sense of culture than that frequently used by American sociologists (e.g., Parsons). Here, culture is used in the sense of Bourdieu (1979) and refers to non-work, chosen activities connected with leisure and consumption.

5 Some issues related to this conceptualization are detailed in Endnote 6.

6 Laflamme (personal communication) has expressed an alternative viewpoint. He claimed that the theoretical categories might be accurate and actual beliefs might be contradictory and inconsistent. In that event, it would be important not to base a theoretical classification on factor analysis. Some arguments for this general view are presented in 
Laflamme (1986). Imputations of rationality or contradiction to respondents are among the most heavily debated in the whole enterprise of social science with such heavyweights as Strawson, Quine, Habermas and Gellner taking positions. The argument made in this article that factor analysis is appropriate assumes that the categorizations in theory must reflect the categorizations made by respondents themselves, but this view is only one possible view which requires strong assumptions which cannot be justified here. However, if one accepted an alternative view that theoretical conceptions may be quite accurate but different from those of respondents, it would still be necessary and important to document these differences and to produce an account of the process producing the structure containing the specific contradictions. Under either choice of metaphysic, it is useful to discover which attitudes maximally cohere with one another.

7 Note that since the factors are orthogonal, their influences on any dependent variables are independent and separable. Hence, one-way analyses are appropriate.

8 All specific differences cited in this section are based on Scheffé post-hoc tests as indicated in Table 2.

${ }^{9}$ It is unfortunate that the data only allow a cross-sectional analysis. The problem with this is that entry and exit effects are not controlled. In particular, some post-secondary students may have withdrawn from the sample. This change will likely effect responses to different questions differently. The most severe effect would be from students who change out of French education into English education and therefore are not sampled. We do not know if the attitudes of these students would be different. However, this certainly represents a small minority of the total group. In addition, as in all crosssectional studies, there may also be a cohort or generational effect.

10 This result was pointed out by Laflamme and Dennie (1990).

11 This result was also shown by Laflamme and Dennie (1990).

\section{References}

Bourdieu, P. (1979). Distinction: A social critique of the judgement of taste. Cambridge, Mass: Harvard University Press.

Colomer, J.M. (1990). The utility of bilingualism: A contribution to a rational choice model of language. Rationality and Society, Vol. II(3).

Hakuta, K. (1986). Mirror of language: The debate on bilingualism.. New York: Basic.

Laflamme, S. (1986). Mirror of language: The debate on bilingualism. New York: Basic.

Laflamme, S., \& Dennie, D. (1990). L'ambition démesurée. Sudbury: Institut Francoontarienne.

Porter, M.R., Porter, J., \& Blishen, B.R. (1979). Does money matter? Toronto: Macmillan of Canada, in association with the Institute of Canadian Studies.

Ryan, T.J. (1972). Poverty and the child. Canada: McGraw-Hill Ryerson, Limited.

Spector, P. (1992). Summated rating scale construction: An introduction. London: Sage Publications.

Tepperman, L. (1988). Choices and chances. Toronto: Holt, Rinehart \& Winston of. Canada, Limited. 
Willis, P. (1977). Learning to labour: How working class kids get working class jobs. Farnborough: Saxon House.

Wilson, J.D. (1981). Canadian education in the 1980's. Calgary, Alberta: Detselig Enterprises Limited. 